\title{
Differences in water depth determine leaf-litter decomposition in streams: implications on impact assessment reliability
}

\author{
A. Martínez ${ }^{1, \star}$, A. Basaguren ${ }^{1}$, A. Larrañaga ${ }^{1}, J$. Molinero $^{2}$, J. Pérez ${ }^{1}$, M. Sagarduy ${ }^{1}$ and J. Pozo ${ }^{1}$ \\ ${ }^{1}$ Laboratory of Stream Ecology, Department of Plant Biology and Ecology, University of the Basque Country, P.O. Box 644, \\ 48080 Bilbao, Spain \\ 2 Escuela de Gestión Ambiental, Pontificia Universidad Católica de Ecuador Sede Esmeraldas PUCESE, Espejo y Subida a Santa \\ Cruz s/n, 080150 Esmeraldas, Ecuador
}

Received January 15, 2016 - Revised March 15, 2016 - Accepted March 15, 2016

\begin{abstract}
Leaf-litter decomposition is a widespread functional indicator to assess the stream ecosystem status. However, the spatial location of leaf-bags could distort the impact assessment since intrinsic features of a given site have an important role in the spatial distribution of macroinvertebrates, which could affect decomposition rate. A source of variability that can be easily controlled is the water depth at which bags are incubated in stream bed. Therefore, we tested if water depth within a same mesohabitat (riffles) can determine decomposition rates. Due to the seasonal variability of macroinvertebrate assemblages in temperate regions, the study was performed in autumn-winter and spring to test the consistency of the findings. In three streams from North of Spain 15 mesh bags with alder leaves were placed in riffles covering a gradient of depths. Depth had a positive effect on decomposition rates and biomass of associated total invertebrates and shredders in autumn-winter, fauna variables helping to explain the differences in rates. In spring, depth affected negatively rates, the observed variability being weakly explained by invertebrates, which did not show differences along depth. Despite the opposite trend between seasons, water depth influences the decomposition rates, which may reduce or increase differences among systems if the water depth distribution is greatly biased. Our study highlights the importance of covering a similar range of water depths in the different systems being compared.
\end{abstract}

Key-words: leaf-litter decomposition / water depth / assessment

Résumé - Les différences dans la profondeur de l'eau déterminent la décomposition de la litière dans les rivières : implications sur la fiabilité de l'évaluation de l'impact. La décomposition de la litière est un indicateur fonctionnel très répandu pour évaluer l'état de l'écosystème en rivière. Cependant, la localisation spatiale des sacs de feuilles pourrait fausser l'évaluation de l'impact puisque les caractéristiques intrinsèques d'un site donné ont un rôle important dans la distribution spatiale des macroinvertébrés, ce qui pourrait affecter le taux de décomposition. Une source de variabilité qui peut être facilement contrôlée est la profondeur de l'eau à laquelle les sacs sont incubés dans le lit du cours d'eau. Par conséquent, nous avons testé si la profondeur de l'eau au sein d'un même mésohabitat (radiers) peut déterminer le taux de décomposition. En raison de la variabilité saisonnière des assemblages de macroinvertébrés dans les régions tempérées, l'étude a été réalisée en automne-hiver et au printemps pour tester la cohérence des résultats. Dans trois rivières du nord de l'Espagne, 15 sacs en filet avec des feuilles d'aulne ont été placés dans des radiers couvrant un gradient de profondeurs. La profondeur a eu un effet positif sur les taux de décomposition et la biomasse totale des invertébrés et celle des déchiqueteurs associés en automne-hiver, les variables de la faune aidant à expliquer les différences dans les taux. Au printemps, la profondeur affecte négativement les taux, la variabilité observée étant expliquée faiblement par les invertébrés, ce qui n'a pas montré de différences selon la profondeur. Malgré la tendance inverse entre les saisons, la profondeur de l'eau influe sur les taux de décomposition, ce qui peut réduire ou augmenter les différences entre les systèmes si la distribution de la profondeur de l'eau est fortement biaisée. Notre étude met en évidence l'importance de couvrir une gamme similaire de profondeurs d'eau dans différents systèmes comparés.

Mots-clés : décomposition de la litière / profondeur de l'eau / estimation

\footnotetext{
^ Corresponding author: aingeru.martinez@ehu.es
} 


\section{Introduction}

Streams and rivers are among the most threatened habitats in the world due to human activities (Malmqvist and Rundle, 2002). As these ecosystems provide important services to human welfare, it is essential to understand the consequences of anthropogenic alterations to preserve or restore their integrity (Meybeck, 2003). Although the assessment of stream health (a term that embodies the notion of human values in the evaluation of ecosystems, Rapport et al., 1998) has traditionally been focused on structural variables such as taxonomic composition of aquatic organisms (e.g. Yuan and Norton, 2003), in the last decades the functional indicators, which offer an integrative measurement of the ecosystem status (Young et al., 2008), have grown in importance. Forested streams are energetically dependent on dead organic matter inputs (aquatic hyphomycetes and macroinvertebrates being the primary consumers) from surrounding vegetation (Tank et al., 2010), and thus, leaf-litter decomposition is a key functional process in these ecosystems. The use of leaf-litter decomposition as a functional tool is greatly spread because of two reasons: the sensitivity to a great variety of stressors such as nutrient addition (e.g. Ferreira et al., 2015), land-use changes (e.g. Martínez et al., 2013) or water regulation (e.g. Mendoza-Lera et al., 2012), and the simplicity of the measurement and the low technical equipment required (Bärlocher, 2005).

To estimate decomposition rates, leaf-litter packs are incubated for some time within mesh bags in spots selected in the stream site to be assessed. However, any stream reach has a variety of habitats such as pools, jams, riffles and different substrate sizes with different trapping efficiencies (Hoover et al., 2010) that make the distribution of leaf-litter to be patchy (Webster et al., 2001). Moreover, these mesohabitats also differ in a number of environmental characteristics such as flow velocity and oxygen saturation that affect biological communities (Álvarez-Cabria et al., 2010) and decomposition (Flores et al., 2013). Thus, to reduce the intra-reach variability, leaf bags have been mostly placed in riffles. Nevertheless, within individual geomorphic units as riffles, smaller patches of uniform physical characteristics form discrete micro-habitats that have an important role in the spatial distribution of macroinvertebrates (Brooks et al., 2005; Kobayashi et al., 2013), which could determine decomposition rates. Thus, the spatial location of leaf-bags within riffles could distort impact assessment, reducing the reliability of leaf-litter decomposition as a tool for this purpose. A source of variability that can be easily controlled in these experiments is the water depth at which leaf bags are incubated, and although a recent work of Solagaistua et al. (2015) suggests that decomposition rates might covary with it, this topic has never been specifically addressed in a study.

Therefore, our main goal was to test if water depth can determine leaf-litter decomposition rates. In addition, due to the seasonal variability of macroinvertebrate assemblages in temperate regions (Serra et al., 2015), the study was carried out in autumn-winter and spring to test the consistency of the findings in different seasons. We hypothesize that water depth influence decomposition rate due to the variability of macroinvertebrate distribution, and that this relationship differs between seasons because of the seasonal variability of macroinvertebrate assemblages.

\section{Material and methods}

\subsection{Study site and methodology}

The study was carried out in three low order streams (S1, S2 and S3) with siliceous substrata flowing into the Atlantic Ocean (Northern Spain, mean latitude $43^{\circ} 12^{\prime} 36^{\prime \prime} \mathrm{N}$; mean longitude $\left.3^{\circ} 16^{\prime} 12^{\prime \prime} \mathrm{W}\right)$. The climate is temperate with an average annual air temperature of around $13{ }^{\circ} \mathrm{C}$ and a mean annual precipitation of $1500 \mathrm{~mm}$, evenly distributed throughout the year. The three streams run through mixed deciduous forest, Quercus robur L. being the main tree species at watershed level and Alnus glutinosa (L.) Gaertner dominating the riparian gallery. Anthropological impacts in the watersheds are negligible, all streams showing oxygen-saturated water $(>90 \%)$, with low mineralization $\left(<120 \mu \mathrm{s} . \mathrm{cm}^{-1}\right)$, low alkalinity (0.96-1.75 meq. $\left.\mathrm{L}^{-1}\right)$, neutral $\mathrm{pH}(6.8-7.6)$, and low dissolved nutrient concentrations (nitrate: $444-834 \mu \mathrm{gN} . \mathrm{L}^{-1}$; nitrite: $1.02-1.17 \mu \mathrm{gN} . \mathrm{L}^{-1}$; ammonium: $34.9-46.5 \mu \mathrm{gN} . \mathrm{L}^{-1}$; SRP: 7.9-12.4 $\mu \mathrm{gP} . \mathrm{L}^{-1}$ ).

The decomposition experiments were carried in autumnwinter and spring, starting the incubations on 14 November 2013 and 25 April 2014 respectively. In each stream 15 mesh bags (dimensions $15 \times 20 \mathrm{~cm}, 5$-mm mesh size) with $5 \pm 0.25 \mathrm{~g}$ of air-dried A. glutinosa leaves were placed at the stream bed in riffles covering a gradient of water depths from the centre of the channel to the margins, the ranges being $1.5-17.5 \mathrm{~cm}$ in $\mathrm{S} 1$, $2.0-23.0 \mathrm{~cm}$ in $\mathrm{S} 2,1.5-21.5 \mathrm{~cm}$ in $\mathrm{S} 3$ during autumn-winter and $0.5-19.5 \mathrm{~cm}$ in $\mathrm{S} 1,0.5-20.5 \mathrm{~cm}$ in $\mathrm{S} 2$ and $0.5-22.5 \mathrm{~cm}$ in S3 during spring. Water depth of bags was measured weekly during the experiments, the minimum and maximum values of standard error in water depth being 0.2 and $3.2 \mathrm{~cm}$, respectively. The bags placed in shallowest sites were always in contact with water, the leaves maintaining always wet. An additional set of 5 extra bags was used to calculate the percentage of remnant water in air dried leaves and to estimate initial ashfree dry mass (AFDM) in bags. After $56 \mathrm{~d}$ (autumn-winter) and $40 \mathrm{~d}$ (spring) of incubation, the bags were collected and transported to the laboratory. Leaves were rinsed with stream water (filtered through a $0.2-\mathrm{mm}$ mesh sieve) over a $0.5-\mathrm{mm}$ mesh sieve sorting out the colonizing macroinvertebrates, which were preserved in $70 \%$ ethanol. The leaf-litter was oven-dried to obtain the dry mass $\left(70{ }^{\circ} \mathrm{C}, 72 \mathrm{~h}\right)$ and then ashed $\left(500{ }^{\circ} \mathrm{C}\right.$, $4 \mathrm{~h}$ ) to determine the remaining AFDM. Macroinvertebrates were identified to family level (Oligochaeta to class) counted and sorted between shredders and other functional groups following Tachet et al. (2002). These two groups were oven-dried separately to determine their dry mass.

\subsection{Statistical analysis}

Decomposition rates were calculated using the negative exponential model (Petersen and Cummins, 1974), as follows: $M_{t}=M_{0} \cdot e^{-k t}$, where $M_{t}$ is the remaining AFDM at the end of incubation, $M_{0}$ is the initial mass, $k$ is the decomposition 
rate and $t$ the incubation time (56 and $40 \mathrm{~d}$ since implantation in autumn-winter and spring respectively). Differences in decomposition rates and the macroinvertebrate variables (total density, shredder density, total biomass and shredder biomass) were compared by linear models (factors: mean depth and stream) using the $l m$ function in $\mathrm{R}$ version 2.11.0 (R Development Core Team, 2010). The relationships among macroinvertebrate variables and decomposition rate were also tested (factors: each macroinvertebrate variable and stream) using the Im function. When necessary data were log-transformed.

\section{Results}

During autumn-winter decomposition rates ranged from $0.014-0.037 \mathrm{~d}^{-1}$ in $\mathrm{S} 1$, from $0.010-0.036 \mathrm{~d}^{-1}$ in $\mathrm{S} 2$ and from $0.012-0.080 \mathrm{~d}^{-1}$ in S3. A total of 44 macroinvertebrate taxa were identified, 14 of which, mainly of the families Leuctridae, Nemouridae, Gammaridae, Sericostomatidae and Limnephilidae, were shredders. The density of total macroinvertebrates and shredders ranged from 8-63 and 026 ind. bag ${ }^{-1}$ in S1, from 5-99 and 2-16 ind.bag ${ }^{-1}$ in S2, and from 4-50 and 4-27 ind. bag $^{-1}$ in S3. Meanwhile, the biomass of total invertebrates and shredders ranged from 1.3-37.4 and $1.3-30 \mathrm{mg} . \mathrm{bag}^{-1}$ in $\mathrm{S} 1$, from $0.9-35.6$ and $0.1-24.5 \mathrm{mg} . \mathrm{bag}^{-1}$ in $\mathrm{S} 2$, and from $4.4-57.3$ and $1.8-51.0 \mathrm{mg} . \mathrm{bag}^{-1}$ in S3. In this season, the depth of bag immersion had a positive effect on decomposition rate, total invertebrate biomass and shredder biomass (Figure 1; Table 1). Decomposition rate showed a positive relationship with total invertebrate biomass and shredder biomass (Table 2).

During spring decomposition rates ranged from $0.037-0.124 \mathrm{~d}^{-1}$ in $\mathrm{S} 1$, from $0.016-0.111 \mathrm{~d}^{-1}$ in $\mathrm{S} 2$ and from $0.012-0.101 \mathrm{~d}^{-1}$ in S3. A total of 45 macroinvertebrate taxa were identified, 9 of which, mainly of the families Nemouridae, Gammaridae, Sericostomatidae, Limnephilidae and Lepidostomatidae, were shredders. The density of total macroinvertebrates and shredders ranged from 5-52 and 1-46 ind. bag ${ }^{-1}$ in S1, from 14-144 and 3-23 ind.bag ${ }^{-1}$ in S2, and from 5-109 and 1-16 ind.bag ${ }^{-1}$ in S3. Meanwhile, the biomass of total invertebrates and shredders ranged from $1.1-98.6$ and $0-98.6 \mathrm{mg} \cdot \mathrm{bag}^{-1}$ in $\mathrm{S} 1$, from $1.0-45.2$ and $0.2-$ $43.7 \mathrm{mg} \cdot \mathrm{bag}^{-1}$ in S2, and from 3.4-78.5 and 0-62.6 mg.bag ${ }^{-1}$ in S3. In this season, the decomposition rate differed in relation with depth and among streams (Figure 1; Table 1), but the relationship was not consistent in $\mathrm{S} 1$ (see interaction effect on Table $\left.1 ; r^{2}=0.007 ; p=0.763\right)$. However, the relationship between water depth and decomposition rate was negative, contrary to the observed in autumn-winter. The macroinvertebrate variables did not show a significant relationship with depth (Figure 1; Table 1) and only total macroinvertebrate density was positively related to decomposition rate (Table 2).

\section{Discussion}

Our results indicate that bottom depth has an effect on leaf-litter decomposition rates. In autumn-winter, the observations by Solagaistua et al. (2015), also carried out in autumnwinter, were confirmed, depth enhancing decomposition rate.
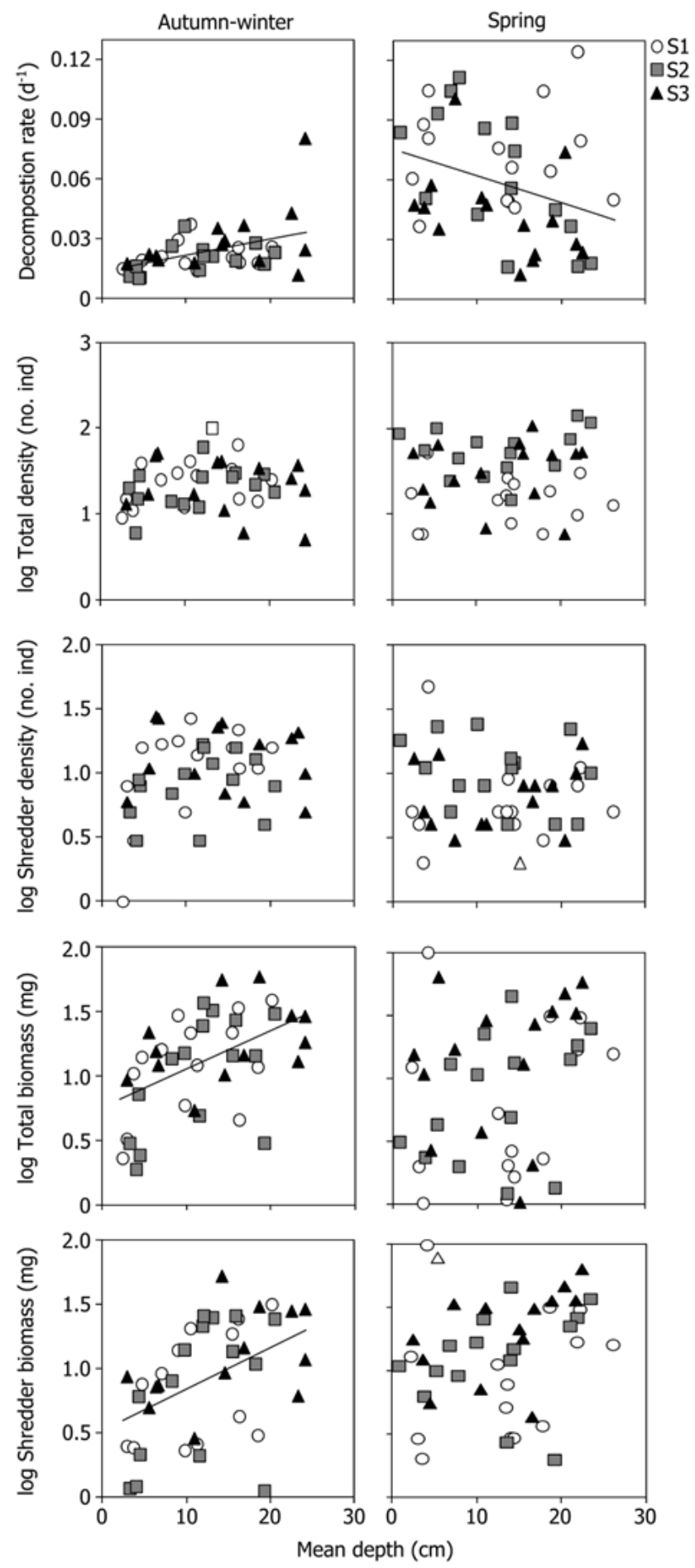

Fig. 1. Mean bag depth $(\mathrm{cm}) v s$. measured variables during autumnwinter and spring.

This variability was related to the differences in biomass of total invertebrates and shredders. The spatial distribution of stream macroinvertebrate assemblages in riffles is greatly explained by the hydraulic conditions created by combinations of velocity, substrate roughness and depth (Brooks et al., 2005). These authors reported that macroinvertebrate abundance was negatively related to depth, a relationship that we did not 
Table 1. Results from the linear model analyses for effects of depth and stream on measured variables during autumn-winter and spring. Significant values are highlighted in bold.

\begin{tabular}{|l|c|c|c|c|c|c|c|}
\hline & & \multicolumn{3}{|c|}{ Autumn } \\
\hline & & $d f$ & $F$ & $p$ & $d f$ & $F$ & $P$ \\
\hline \multirow{3}{*}{ Decomposition rate (d $\mathbf{d}^{-1}$ ) } & Depth & 1,36 & 10.53 & $\mathbf{0 . 0 0 3}$ & 1,39 & 5.62 & $\mathbf{0 . 0 2 2}$ \\
& Stream & 2,36 & 1.36 & 0.268 & 2,39 & 5.52 & $\mathbf{0 . 0 0 7}$ \\
& Depth $\times$ Stream & 2,36 & 0.75 & 0.48 & 2,39 & 3.69 & $\mathbf{0 . 0 3 4}$ \\
\hline \multirow{3}{*}{$\log$ Total density (no. ind) } & Depth & 1,37 & 0.37 & 0.546 & 1,38 & 0.19 & 0.669 \\
& Stream & 2,37 & 0.10 & 0.906 & 2,38 & 11.55 & $<\mathbf{0 . 0 0 1}$ \\
& Depth $\times$ Stream & 2,37 & 1.57 & 0.222 & 2,38 & 0.06 & 0.943 \\
\hline \multirow{3}{*}{$\log$ Shredder density (no. ind) } & Depth & 1,37 & 3.62 & 0.065 & 1,38 & 0.18 & 0.672 \\
& Stream & 2,37 & 1.25 & 0.299 & 2,38 & 2.50 & 0.095 \\
& Depth $\times$ Stream & 2,37 & 2.37 & 0.107 & 2,38 & 0.59 & 0.561 \\
\hline \multirow{3}{*}{$\log$ Total biomass (mg) } & Depth & 1,36 & 12.99 & $\mathbf{0 . 0 0 1}$ & 1,38 & 2.93 & 0.095 \\
& Stream & 2,36 & 0.68 & 0.511 & 2,38 & 1.76 & 0.187 \\
& Depth $\times$ Stream & 2,36 & 0.94 & 0.400 & 2,38 & 0.05 & 0.952 \\
\hline \multirow{3}{*}{$\log$ Shredder biomass (mg) } & Depth & 1,35 & 10.66 & $\mathbf{0 . 0 0 2}$ & 1,38 & 2.32 & 0.136 \\
& Stream & 2,35 & 0.30 & 0.745 & 2,38 & 3.18 & 0.053 \\
& Depth $\times$ Stream & 2,35 & 0.34 & 0.714 & 2,38 & 0.03 & 0.972 \\
\hline
\end{tabular}

Table 2. Results from the linear model analyses for effects of invertebrate variables and stream on decomposition rate during autumn-winter and spring. Significant values are highlighted in bold.

\begin{tabular}{|l|c|c|c|c|c|c|}
\hline & \multicolumn{3}{|c}{ Autumn-winter } & \multicolumn{3}{c|}{ Spring } \\
\hline & $d f$ & $F$ & $p$ & $d f$ & $F$ & $P$ \\
\hline $\log$ Total density (ind) & 1,36 & 2.66 & 0.112 & 1,38 & 7.05 & $\mathbf{0 . 0 1 1}$ \\
\hline Stream & 2,36 & 3.29 & $\mathbf{0 . 0 4 8}$ & 2,38 & 3.94 & 0.027 \\
\hline log Total density (ind) $\times$ Stream & 2,36 & 6.50 & $\mathbf{0 . 0 0 4}$ & 2,38 & 0.96 & 0.391 \\
\hline $\log$ Shredder density (ind) & 1,36 & 0.78 & 0.382 & 1,38 & 0.35 & 0.558 \\
\hline Stream & 2,36 & 2.65 & 0.084 & 2,38 & 4.06 & $\mathbf{0 . 0 2 5}$ \\
\hline log Shredder density (ind) $\times$ Stream & 2,36 & 4.35 & $\mathbf{0 . 0 2 0}$ & 2,38 & 1.52 & 0.231 \\
\hline log Total biomass $(\mathbf{m g})$ & 1,35 & 9.76 & $\mathbf{0 . 0 0 3}$ & 1,38 & 0.17 & 0.683 \\
\hline Stream & 2,35 & 1.03 & 0.367 & 2,38 & 4.72 & $\mathbf{0 . 0 1 5}$ \\
\hline log Total biomass (mg) $\times$ Stream & 2,35 & 0.25 & 0.778 & 2,38 & 0.32 & 0.729 \\
\hline log Shredder biomass (mg) & 1,34 & 15.74 & $<\mathbf{0 . 0 0 1}$ & 1,38 & 0.00 & 0.992 \\
\hline Stream & 2,34 & 1.04 & 0.364 & 2,38 & 4.60 & $\mathbf{0 . 0 1 6}$ \\
\hline log Shredder biomass (mg) $\times$ Stream & 2,34 & 1.62 & 0.211 & 2,38 & 0.20 & 0.820 \\
\hline
\end{tabular}

found. However, our results of biomass (both of total invertebrates and shredders) distribution agree with Kobayashi et al. (2013), deepest areas presenting higher values of invertebrate biomass than shallower ones.

In spring, the effect of depth on decomposition rate showed a trend opposite to that in autumn-winter. Despite the expected seasonality of the structure of macroinvertebrate assemblage (Serra et al., 2015), it was expected the spatial distribution of macroinvertebrates to be related to depth. Again, density or biomass would be the explanatory variables for the decomposition rates measured. However, the observed variability in decomposition rates in spring was weakly explained by the density and biomass of macroinvertebrates, which did not show differences along depth. This lack of differences may be related to the sampling technique rather than the spatial distribution of assemblages. We studied the macroinvertebrates colonizing the leaf bags, and in spring, the remaining AFDM in the shallower areas was lower than $15 \%$, with only the most re- fractory portion of leaf material (nerves and petioles) left. This part of the leaves is not attractive for consumers because of its low nutritional quality and toughness. Thus, although we can predict higher densities and abundances of invertebrates in the benthos of shallower parts in spring from the decomposition rates observed, we might just had collected the bags after the invertebrates had abandoned them due to the lack of nutritious portions of leaves.

In any case, even if we have observed positive and negative relationships depending on the season, our study highlights that leaf decomposition rate can correlate with the water depth the bags are placed on. This covariation may reduce or increase differences among systems if the water depth distribution is greatly biased. Although it is difficult to standardize the incubation of bags for water depth, our study highlights the importance of covering a similar range of water depths in the different systems being compared. 
Acknowledgements. This study was funded by the Spanish Ministry of Science and Innovation (Projects CGL2010-22129-C04-01 and CGL2011-23984) and by the Basque Government (Research Grant IT-302-10). A. Martínez was granted by the University of The Basque Country, UPV/EHU. Jon Molinero is currently a PROMETEO researcher for the Secretaría de Educación Superior, Ciencia, Tecnología e Innovación (SENESCYT) of Ecuador.

\section{References}

Álvarez-Cabria M., Barquín J. and Juanes J.A., 2010. Spatial and seasonal variability of macroinvertebrate metrics: Do macroinvertebrate communities track river health? Ecol. Indic., 10, 370-379.

Bärlocher F. 2005. Leaf mass loss estimated by litter bag technique. In: Graça M., Bärlocher F. and Gessner M. (eds.), Methods to study litter decomposition: A practical guide, Springer, Berlin, 37-42.

Brooks A.J., Haeusler T., Reinfelds I. and Williams S., 2005. Hydraulic microhabitats and the distribution of macroinvertebrate assemblages in riffles. Freshwater Biol., 50, 331-344.

Ferreira V., Castagneyrol B., Koricheva J., Gulis V., Chauvet E. and Graça M.A.S.., 2015. A meta-analysis of the effects of nutrient enrichment on litter decomposition in streams. Biol. Rev., 90, 669-688.

Flores L., Díez J.R., Larrañaga A., Pascoal C. and Elosegi A., 2013. Effects of retention site on breakdown of organic matter in a mountain stream. Freshwater Biol., 58, 1267-1278.

Hoover T.M., Marczak L.B., Richardson J.S. and Yonemitsu N. 2010. Transport and settlement of organic matter in small streams. Freshwater Biol, 55, 436-449.

Kobayashi S., Amano K. and Nakanishi S., 2013. Riffle topography and water flow support high invertebrate biomass in a gravel-bed river. Freshwater Sci., 32, 706-718.

Malmqvist B. and Rundle S., 2002. Threats to the running water ecosystems of the world. Environ. Conserv., 29, 134-153.

Martínez A., Larrañaga A., Pérez J., Descals E., Basaguren A. and Pozo J., 2013. Effects of pine plantations on structural and functional attributes of forested streams. Forest Ecol. Manag., 310, $147-155$.
Mendoza-Lera C., Larrañaga A., Pérez J., Descals E., Martínez A., Moya O., Arostegui I. and Pozo J., 2012. Headwater reservoirs weaken terrestrial-aquatic linkage by slowing leaf-litter processing in downstream regulated reaches. River Res. Appl., 28, 13-22.

Meybeck M., 2003 Global analysis of river systems: from Earth system controls to Anthropocene syndromes. Philos. Trans. R. Soc. $B, 358,1935-1955$.

Petersen R.C. and Cummins K.W., 1974. Leaf processing in a woodland stream. Freshwater Biol., 4, 343-368.

R Development Core Team, 2010. R: A language and environment for statistical computing. R Foundation for Statistical Computing, Vienna, Austria. ISBN 3-900051-07-0, Available from: http:// www.R-project.org

Rapport D.J., Costanza R. and McMichael A.J., 1998. Assessing ecosystem health. Trends Ecol. Evol., 13, 397-402.

Serra S.R.Q., Calapez A.R., Pérez-Bilbao A. and Feio M.J., 2015. Adjusting the effect of seasonal variability in the bioassessment of streams. Environ. Monit. Assess., 187, 4107.

Solagaistua L., Arroita M., Aristi I., Larrañaga A. and Elosegi A., 2015. Changes in discharge preferentially affects surface more than subsurface breakdown of organic matter in a mountain stream. Mar. Freshwater Res., DOI: 10.1071/MF14408.

Tachet H., Richoux P., Bournaud M. and Usseglio-Polatera P., 2002. Invertébrés d'eau douce: systématique, biologie et écologie, CNRS, Paris, 587 p.

Tank J.L., Rosi-Marshall E.J., Griffiths N.A., Entrekin S.A. and Stephen M.L., 2010. A review of allochthonous organic matter dynamics and metabolism. J. N. Am. Benthol. Soc., 29, 118-146.

Webster J.R., Benfield E.F., Hutchens J.J., Tank J.L., Golladay S.W. and Adams J.C. 2001. Do leaf breakdown rates actually measure leaf disappearance from streams? Int. Rev. Hydrobiol., 86, $417-$ 427.

Yuan L.L. and Norton S.B., 2003. Comparing responses of macroinvertebrate metrics to increasing stress. J. N. Am. Benthol. Soc., $22,308-322$.

Young R.G., Matthaei C.D. and Townsend C.R., 2008. Organic matter breakdown and ecosystem metabolism: functional indicators for assessing river ecosystem health. J. N. Am. Benthol. Soc., 27, 605-625. 